\title{
The occurrence of Pontoporia blainvillei (Gervais \& d'Orbigny) (Cetacea, Pontoporiidae) in an estuarine area in southern Brazil
}

\author{
Marta J. Cremer ${ }^{1} \&$ Paulo C. Simões-Lopes ${ }^{2}$ \\ ${ }^{1}$ Departamento de Ciências Biológicas, Universidade da Região de Joinville. Caixa Postal 110, 89240-000 São Francisco do \\ Sul, Santa Catarina, Brasil. E-mail: mcremer@ilhanet.com.br (contact author) \\ ${ }^{2}$ Departamento de Ecologia e Zoologia, Universidade Federal de Santa Catarina. Caixa Postal 5102, 88040-970 \\ Florianópolis, Santa Catarina, Brasil. E-mail: lamaqsl@ccb.ufsc.br
}

\begin{abstract}
The toninha, or franciscana, Pontoporia blainvillei (Gervais \& D'Orbigny, 1844), is an endemic species of cetacean of the southwestern Atlantic Ocean. There is little information on the occurrence of this species in its natural environment due to the great difficulty in sighting it. Systematized and non-systematized observations of franciscanas were made from December 1996 through November 2001 at Babitonga Bay, on the northern coast of Santa Catarina State, southern Brazil. The observations were made from small motorboats. A total of 79 observations were made, totaling 561 individuals. Up to $59.5 \%$ of the groups consisted of over four individuals and the average group size was seven. Calves were present in $30.4 \%$ of the observations. The species was found throughout the year within the bay and preferential areas were identified. Calves were registered during all seasons. Data are presented on the behavior (feeding, traveling, aerial behavior and behavior relating to the boats) and on interspecific interactions with terns, cormorants [Phalacrocorax brasilianus (Gmelin, 1789)] and brown boobies [Sula leucogaster (Boddaert, 1783)]. The species is sympatric with the estuarine dolphin Sotalia guianensis (P. J.Van Bénéden, 1864) in the bay, but there was no record of interaction between them. The area of the bay represents an important refuge for the franciscana species.

KEY WORDS. Behavior, group size, distribution, South America.
\end{abstract}

RESUMO. Ocorrência de Pontoporia blainvillei (Gervais \& d'Orbigny) (Cetacea, Pontoporiidae) em uma região estuarina no sul do Brasil. A toninha, ou franciscana, Pontoporia blainvillei (Gervais \& D’Orbigny, 1844), é uma espécie endêmica de cetáceos que ocorre no Oceano Atlântico sul ocidental. Existem poucas informações sobre a ocorrência da espécie em seu ambiente natural em função da grande dificuldade em avistá-la. Observações sistematizadas e não-sistematizadas de franciscanas foram realizadas no período entre dezembro de 1996 e novembro de 2001 na Baía da Babitonga, no litoral norte do estado de Santa Catarina, sul do Brasil. As observações foram realizadas a partir de pequenas embarcações a motor. Um total de 79 observações foram efetuadas, totalizando 561 indivíduos. Acima de $\mathbf{5 9 . 5 \%}$ dos grupos eram compostos por mais de quatro indivíduos e a média de tamanho de grupo foi de sete. Filhotes estiveram presentes em $30.4 \%$ das observações. A espécie foi encontrada na baía ao longo de todo o ano e foram identificadas áreas de uso preferencial. Filhotes foram registrados em todas as estações. São apresentadas informações sobre o comportamento (alimentação, deslocamento, comportamentos aéreos e relativos a embarcações) assim como sobre interações interespecíficas com trinta-réis, biguás [Phalacrocorax brasilianus (Gmelin, 1789)] e atobás marrons [Sula leucogaster (Boddaert, 1783)]. A espécie é simpátrica do golfinho estuarino Sotalia guianensis (P. J.Van Bénéden, 1864) na baía, mas não foram efetuados registros de interação entre ambas as espécies. $\mathrm{A}$ área da baía representa um importante refúgio para a franciscana.

PALAVRAS CHAVE. Comportamento, tamanho de grupo, distribuição, América do Sul.

The franciscana, Pontoporia blainvillei (Gervais \& D'Orbigny, 1844) (Pontoporiidae), is an endemic species of the southwestern Atlantic, and occurs from Espírito Santo, southeastern Brazil (18²5'S) (Siciliano 1994) down to the Golfo Nuevo in the Valdéz Peninsula, Argentina (42³5'S) (Crespo et al. 1998). Along the Brazilian coast, this species is referred to as "toninha", but the international scientific community prefers its Spanish name, "franciscana". It inhabits coastal areas from the coastline up to a depth of $30 \mathrm{~m}$ or 25 nautical miles from the shore (Praderi et al. 1989). The species is listed as "data deficient" in the IUCN Red Book (IUCN 2000).

Due to its cryptic coloration, small size and discrete be-

Revista Brasileira de Zoologia 22 (3): 717-723, setembro 2005 
havior, there is little information about this species in the natural environment. Opportunistic observations have been made in recent years at different localities, such as in Argentina (CRESPO et al. 1998) and Brazil (Di BeneditTo et al. 2001). In Baía Anegada, Argentina, it appears throughout the whole year (Bondino et al. 1999). The only population estimate for the species so far was conducted on the southern coast of Rio Grande do Sul State, southern Brazil, where the population density was estimated as being 0.657 animals $/ \mathrm{Km}^{2}$ (SECCHI et al. 2001). The species seems to exhibit a limited behavioral repertoire, with the absence of aerial displays (Bordino et al. 1999). Diving patterns were registered by BoRDino et al. (1999), with a mean dive time of $21.7 \mathrm{sec}$.

Most studies have investigated individuals accidentally captured by fishing nets, or found dead on the beach. Pontoporia blainvillei is considered to be one of the species with the highest number of accidental captures throughout its area of occurrence (Praderi et al. 1989, PINEDo 1991). Its coastal habitat coincides with areas of highest fishing activity, both artesanal and industrial, which makes it subject to an intense use of gillnets and explains most of the captures. Thus, the implementation of conservation strategies for the species requires a broader knowledge of the ecological factors related to its occurrence in the habitat it occupies, as well as of its behavioral characteristics. Information about the species in its natural environment is essential for the elucidation of important issues related to its ecology.

This paper presents information about the ecology and behavior of $P$. blainvillei collected during a field study on the ecology of estuarine dolphins, Sotalia guianensis (P. J. Van Bénéden, 1864), conducted in Babitonga Bay, southern Brazil. Although the name tucuxi dolphin is of common use, it should be noted that the word tucuxi means "fresh water dolphin". So the authors used the term estuarine dolphin that is in common use along the Brazilian coast.

\section{MATERIAL AND METHODS}

\section{Study Area}

Babitonga Bay is located in the north of Santa Catarina State, southern Brazil, between $26^{\circ} 02^{\prime}-26^{\circ} 28^{\prime} S$ and $48^{\circ} 28^{\prime}$ $48^{\circ} 50^{\prime} \mathrm{W}$, comprising an area of approximately $160 \mathrm{Km}^{2}$. It is $21 \mathrm{~km}$ long and $5 \mathrm{~km}$ maximum wide, and is connected to the ocean through a deep canal, about $1.7 \mathrm{~km}$ wide. Its surroundings cover approximately $6,201.54$ ha of mangrove vegetation, with margins also including sand beaches and rocks, presenting 83 islands, stone slabs and tidal sandbanks. The bay receives many rivers, being considered however a homogeneous estuary (IBAMA 1998). The maximum depth is $28 \mathrm{~m}$ in the main canal used to reach the São Francisco do Sul harbor, with a mean depth of $6 \mathrm{~m}$, and extremely shallow areas close to the sandbanks. The variation of the tide has a range of $2.3 \mathrm{~m}$, according to the tide-table for the port of São Francisco do Sul.

\section{Data collection}

The present data were collected between December 1996 and November 2001. Different efforts were made throughout this time. Between December 1996 and September 1997, a total of $160 \mathrm{~h}$ were spent in the field, and between December 1997 and November 1998 a total of 422 h were spent. During these periods, opportunistic observations of $P$. blainvillei were registered by one or two observers during the accompaniment of S. guianensis groups, using the focal group sampling method, traveling the entire bay in all months of the year. Between October 2000 and November 2001, the collection of data was conducted throughout using the line transect sampling method, with two observers and always in sea conditions below Beaufort 2. During this period we totaled $689.5 \mathrm{~km}$ and $77 \mathrm{~h}$ spent in the field. During the preceding period between December 1998 and September 2000, no field research was conducted.

Sightings were made from different boats, which varied in length from 4.5 to $7 \mathrm{~m}$, equipped with $15,18,25$ or $40 \mathrm{Hp}$ outboard motors. For each sighting, we recorded the position, using a Garmin 45 GPS, the number of individuals, the presence of calves, fishing boats, nets, birds and estuarine dolphins (S. guianensis), and the behavior of the group. Our definition of the term "group" follows SHANe (1990), which establishes it as "any group of dolphins sighted in apparent association, moving in the same direction, and often, but not always, engaged in the same activity." We considered as calves the animals that remained side by side with an adult and had a maximum of one half the adult's length. The depth at the location of the sighting was normally recorded with sonar. When this was not possible, the isobath of the navigation cards was used. The observation of the behavior followed the 'ad libitum' method (AltMan 1974), also described as 'anecdotal' reports, widely considered as a valuable means of describing rarely-observed events (MANN 1999). The period of observation of a group varied according to the environmental conditions and the behavior of the group, and the sightings were made with the engines on or off, depending on the conditions of the sea. Binoculars of $7 \times 40 \mathrm{~mm}$ were used, as well as $35 \mathrm{~mm}$ photographic cameras equipped with $28-210 \mathrm{~mm}$ zoom lenses.

The spots registered were subsequently plotted on navigation charts Nos. 1804 and 1805 of the DHN (Board of Naval Hydrography). The charts were divided into squares of approximately $0.77 \mathrm{~km}^{2}$, following the geographic coordinates every 30 ".

\section{RESULTS}

Seventy-nine groups of $P$. blainvillei were sighted during the study period, and $16.5 \%$ of the total were subjected to the transect method. The sightings totaled 561 individuals, including 43 calves. The franciscana was seen during all seasons in Babitonga Bay.

Our observations suggested that the conditions of the sea constitute a fundamental factor in the detection of this 
particular species. No occasional sightings were made with a Beaufort above 2 .

The group size varied from one to 22 individuals, with an average of 7.1 individuals per group (7.1 $\pm 5.42 \mathrm{SD}, \mathrm{n}=79)$. Solitary individuals correspond to $3.8 \%$ of the sightings, while groups of two and three individuals were the most frequent, corresponding to $35.4 \%$ of the groups sighted. A total of $59.5 \%$ of the groups consisted of more than four individuals. The presence of calves was observed during all seasons in 30.4\% of the groups. Mother-calf pairs were not observed in isolation, and there were never less than two adults around a calf. The correlation between number of calves and number of adults in the group was not significant $(\mathrm{r}=0.21, \mathrm{n}=79, \mathrm{p}>0.05)$.

Pontoporia blainvillei tend not to form tight groups, presenting an internal formation of subgroups. The motion of the subgroups suggests a certain fluidity, but so far it has not been possible to describe the pattern with precision. Subgroups may or may not display the same behavior, but they keep relatively close to each other and move in the same direction.

Depths at sighting locations ranged from two to $10 \mathrm{~m}$, with an average of $7.5 \mathrm{~m}$. The shallowest areas corresponded to long sandbanks, which could be sighted during low tide, or areas close to the shore, near mangroves that presented a smooth declivity. The species was sighted very near (up to 20 $\mathrm{m}$ from) the margins formed by mangrove and rocks which were very close to islands and the mainland, but it was never sighted in the vicinity of margins formed by sand.

Two concentration areas of franciscanas were noted, both of which were in the innermost portions of the bay (Fig. 1). These areas are characterized by the presence of islands, canals and sandbanks, resulting in very heterogeneous bottom topography, with a sand-and-muddy formation. In the regions facing the canal of access to the ocean, the species was never sighted.

We were able to identify two behavioral categories: a) Traveling: Franciscanas present a swimming pattern that differs from that of the majority of the small cetaceans. After many of its dives, its long rostrum is the first to appear, projecting itself out of the water, quickly followed by the back, which moves with a very discrete curvature, exposing only a small portion of the body (Fig. 2). Neither their backs nor their fins show any kinds of marks such as cuts or scratches. The fin virtually does not cut the waterline, emerging and submerging vertically; b) Foraging: Feeding behaviors are very discrete and some movements suggest the activity of fishing, although it is not possible to see the animals with fish in their mouths. The movement of the individuals on the surface is like a feeding rush that suggests a fishing activity, similar to that which occurs with other small cetaceans. In some circumstances, the group moves slowly in the same area with a variable direction, in an activity possibly related to the search for prey, with sporadic captures [= exploratory fishing by SHANE (1990)]. On some occasions, the individuals slide their bodies laterally at the moment they dive, probably positioning their sonar. When they

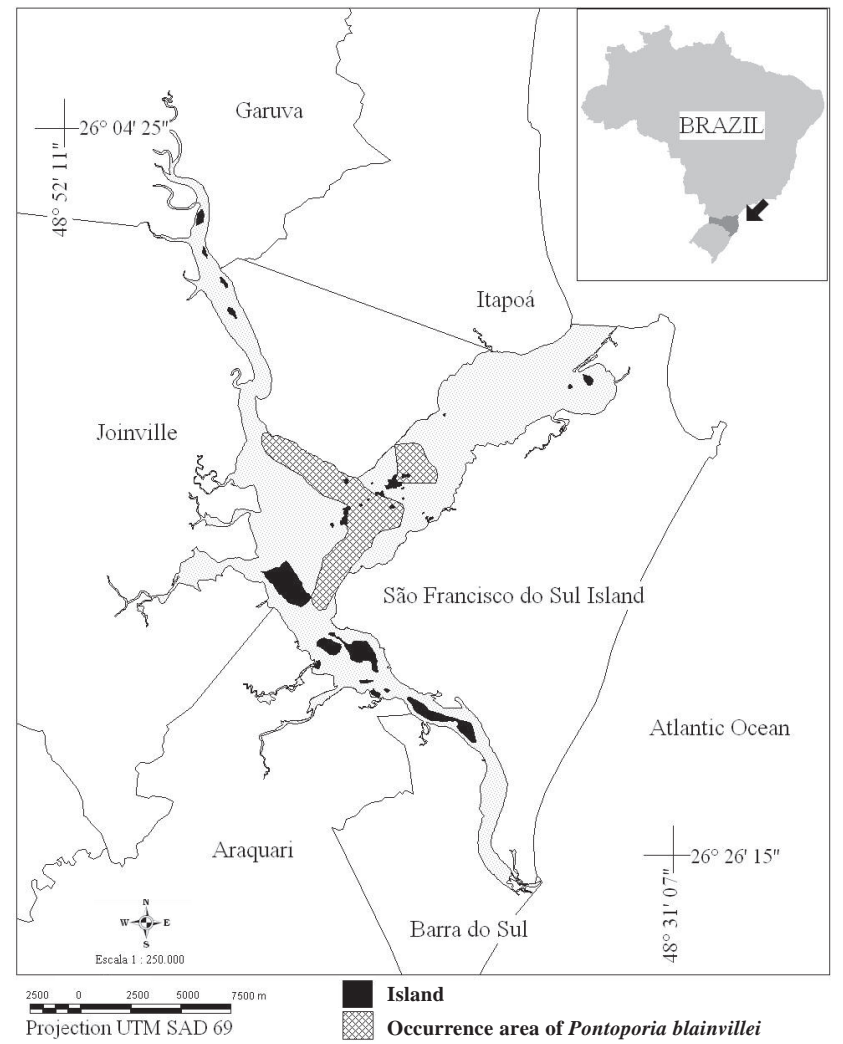

Figure 1. Concentration areas of Pontoporia blainvillei in Babitonga Bay, Southern Brazil.

are members of large groups, they usually mantain a general formation of subgroups of 1 to 5 individuals. Such subgroups may arrange themselves in circles, possibly to surround shoals of fish. Movements in opposite directions may also be observed ( = cross fishing by Monteiro-Filho (1992) for S. guianensis). On various occasions the species can be seen fishing on the sandbanks during high tide, at depths of between 2 and $5 \mathrm{~m}$.

The species exhibits a reduced repertoire of surfacing behavior. Only three patterns were observed: forward leap, tail slap and spy hope. Forward leap was observed only once, while observing a group of 11 adults and 4 calves. Tail slap was observed during fishing activity. However, the flukes were not completely exposed, and were kept parallel to the surface. Spy hope was performed several times, with the rostrum pointed toward the boat. Some individuals from the group came closer to the boat and immersed their heads laterally.

Twenty-four interactions between franciscanas and birds were registered, involving three bird species $(30.4 \%, \mathrm{n}=79)$. Terns were the most frequent, accounting for $79.1 \%$ of the events $(\mathrm{G}=73.2, \mathrm{df}=2, \mathrm{p}<0.05)$. The groups of birds consisted of one to 15 individuals, while the groups of franciscanas included two to 17 individuals. While the franciscanas were apparently fish- 


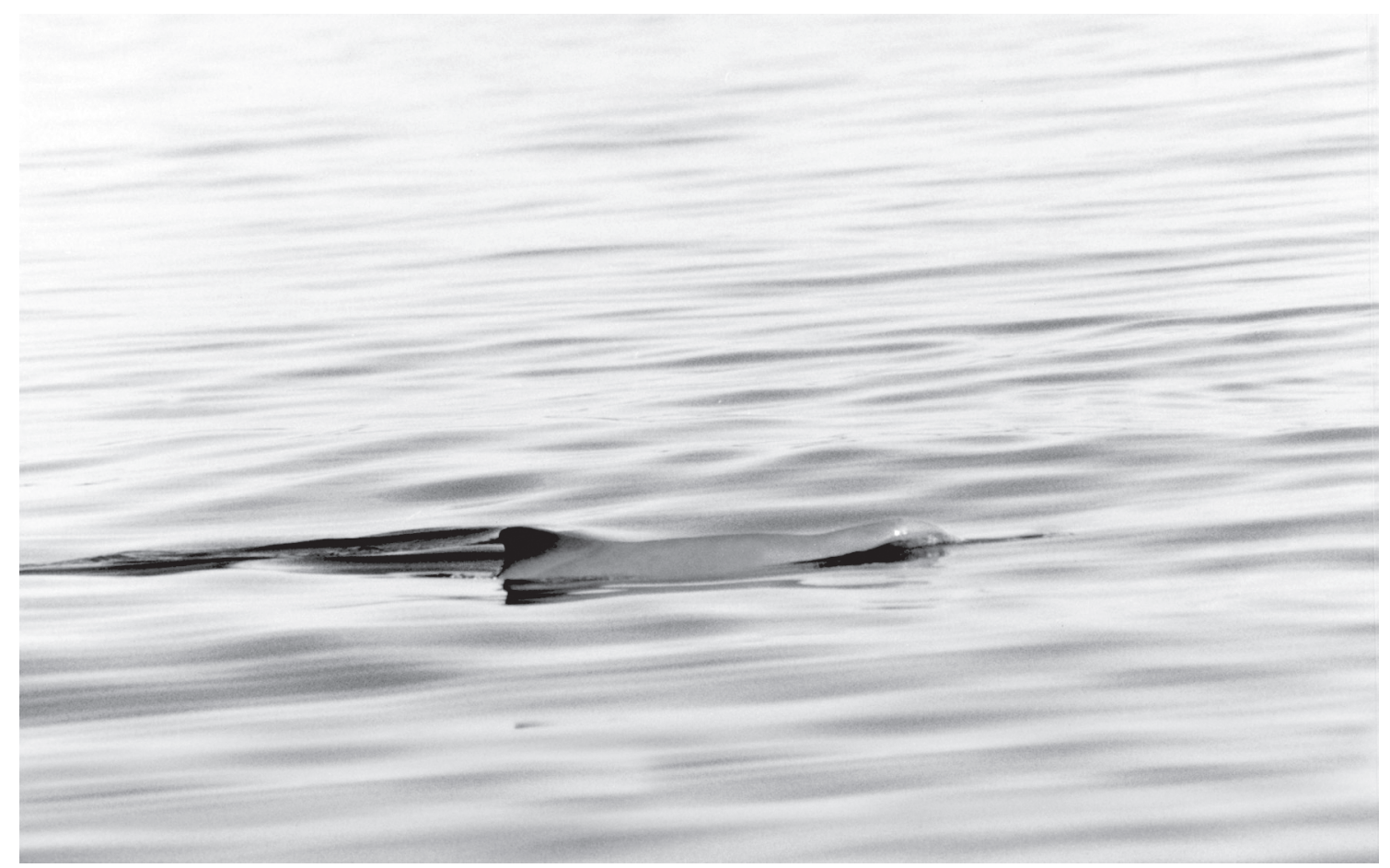

Figure 2. Surfacing in franciscana dolphin, Pontoporia blainvillei.

ing, the terns came close and flew over the group, diving frequently towards the water and performing an intense vocalization. The initiative to interact was always displayed by the terns, never by the franciscanas. These events were observed in a number of areas in the bay, and on some occasions, they helped us to locate the franciscanas. On two occasions, the interaction occurred between the franciscanas and the cormorant Phalacrocorax brasilianus (Gmelin, 1789), in which only one bird participated together with two groups of six and 15 franciscanas. In these interactions, the cormorant remained floating on the water, but dived together with the franciscanas. Interaction with the brown booby Sula leucogaster (Boddaert, 1783) was less frequent and was similar to that occurring with other dolphin species.

No interactions between franciscanas and S. guianensis dolphins were observed. On some occasions, both species could be sighted simultaneously, with a minimum distance of $100 \mathrm{~m}$ between the groups, but it was never possible to note any behavioral change due to such proximity for either of the two species.

The boat traffic in the area can influence the behavioral pattern of the groups. When the animal notes the approaching boat it begins to emerge gradually in a more discrete way, i.e., a much reduced portion of its body is exposed, and when it dives it stays underwater for longer periods. In a first moment, the individuals may swim away from the area, but they tend to return to the site where they were before, even if the boat keeps the engine on, and they may emerge in a normal pattern again, with their backs becoming more apparent. Another behavior displayed by the group was to disperse when boats were passing.

\section{DISCUSSION}

The presence of franciscanas throughout the year in Babitonga Bay suggests that the species uses the area continuously. Di Beneditto et al. (2001) recorded the species during all seasons in the north of Rio de Janeiro, southeastern Brazil, based on information given by fishermen. The same was noted by Bordino et al. (1999) in Anegada Bay, Argentina. However, these authors noted a seasonal pattern of occurrence in correlation with the water temperature. The tide has a direct influence on the occurrence of franciscanas over the sandbanks, which are used for fishing during high tide. But no correlation between the tide and the entrance or exit of the animals from the bay was noted, as mentioned by BorDino et al. (1999).

Babitonga Bay is used selectively by the franciscanas, with a marked preference for certain areas. According to ScHOENER (1971), a population's home range can be used in a non-homogenous way, according to the availability of food in specific areas. Most of the groups of primates, who have relatively small living areas, know the distribution of food resources very well (Clutton-Brock \& Harvey 1977). Thus, it is probable that dolphins tend to visit regularly the areas in which they have found food on other occasions, reducing the energy cost in their search 
for food. In this way, the distribution of franciscanas in Babitonga Bay is probably strongly influenced by the distribution of fish in the area. The occurrence of concentration areas for the species and the lack of sightings at the mouth of the bay suggest that this is a resident population, as has been recorded for $S$. guianensis in the same area using photoidentification techniques (CRemer et al. 2004a).

The estuary of Babitonga Bay is considered to be one of the largest in the state of Santa Catarina, and stands as an important area for the reproduction of the marine ichthyofauna, which is mainly represented by species from the Scianidae, Engraulidae, Carangidae and Gerreidae families (Iвама 1998). Dietary studies indicate that $P$. blainvillei feed mainly on fishes from the Scianidae, Batrachoididae, Trichiuridae and Engraulidae families and also on shrimp, especially during the species' first stages of development (FITCH \& BRownell 1971, Brownell 1975, Pinedo et al. 1989). In estuarine areas in northern Argentina, the scianids are the most frequently found prey (Rodríguez et al. 2002). Preliminary information about the diet of the species in Babitonga Bay indicates that scianid and engraulid species are the main prey (MARCUCCI \& CREMER 2003).

Brownell (1989) and Pinedo et al. (1989) suggest that the species is not gregarious. However, records from recent years show that the species is not solitary, though most of the records are of small groups. On the coast of Rio de Janeiro the size of the groups ranges from 1 to 10 individuals (Di BENEDITTO et al. 2001). In Anegada Bay, Bordino et al. (1999) recorded an average of 2.6 individuals per group. In Babitonga Bay it was noted that solitary individuals were not frequent, and the species tended to form larger groups than in other areas. Mother-calf groups, which comprised $2 \%$ of the sightings at Anegada Bay (Bordino et al. 1999), were not observed in Babitonga Bay.

The species seems to exhibit a reduced repertoire of behavior, as already noted by Bordino et al. (1999), but the occurrence of surface behavior is described for the first time in this work, and our observations indicate that such behavior is not frequent for the species. The fishing activity of the franciscanas in shallow areas close to the margin may represent a way to facilitate the capture of prey. The use of barriers to capture fish is already known for other coastal species, such as Tursiops truncatus (Montagu, 1821) (Irvine et al. 1981, Santos \& Lacerda 1987, Shane 1990) and S. guianensis (MonTeIro-FilHo 1995). The water surface may also be used as a barrier, when the dolphins bring the shoal from the bottom to capture the fish at the waterline, a move made easier by shallow areas (WüRSIG 1986). It is probable that the concentration of groups in areas in which the depth is highly heterogeneous is related to the greater availability of niches for the prey and, consequently, of opportunities for foraging.

The occurrence of interactions with sea birds during feeding events was also observed by BorDino et al. (1999), who recorded three species of Larus during fishing activities. Even though Larus dominicanus is a common species in Babitonga Bay, it was never seen interacting with the franciscanas. The interaction with birds in this area can occur with three species of sea birds and it is characterized as commensalistic in all the cases, similar to that observed for $S$. guianensis in the same area (Cremer et al. 2004b). No interaction between P. blainvillei and S. guianensis was observed, although the latter can also be observed throughout the year in Babitonga Bay, in spite of a significant overlap in the areas used by both species.

One of the main areas used by P. blainvillei came to be an area of intense traffic of fishing and leisure boats, which travel at high speed. This contradicts the data in the literature, which suggests that they usually avoid motor boats (BROwNELL 1989, BoRDino et al. 1999). The continual use of an area with intense boat traffic may reflect the significance of this area for the population, and not necessarily the lack of impact on the animals (RichaRdson et al. 1995). In addition, it was possible to confirm that the animals displayed a specific behavior in relation to the boats, such as longer dives and the dispersion of the group, possibly thus reducing the risk of accidents. There was no record of wounded or dead dolphins due to collisions with boats. Nonetheless, the permanence of the franciscanas in these areas shows the existence of a certain level of tolerance to such a disturbance, as has already been verified for some other species of cetaceans during whale-watching (WATKINS 1986). During our research, the fact that some animals approached the boat also indicated their tolerance to the noise in the area, since it was possible to stay close to the groups with the boat engine at low revolution, a behavior not previously described for the species.

Our observations suggest that Babitonga Bay is an area of great relevance to the species as a site for feeding, resting and nursing. Because it is a protected estuary, it exhibits calm and shallow waters, with mild temperatures during the whole year, as well as the absence of large predators, such as sharks (BrownelL 1975, Praderi 1985, Ibama 1998), and a high productivity. The occurrence of the species in estuarine regions has already been registered for the La Plata river estuary, Argentina (XIMENEz et al. 1972, Praderi 1985). However, there is no record of the species in the other main estuaries along the Brazilian coast.

\section{ACKNOWLEDGEMENTS}

The authors sincerely thank Míriam Albrecht, Fernando Brutto, Daniela Sanfelice, Antonio J. Tonello Jr. and Fernando A. S. Hardt for their collaboration during the gathering of field data at different moments. The first author is extremely grateful for the financial and institutional support given by the Universidade da Região de Joinville, through their Fundo de Apoio à Pesquisa. Financial support was also given by the Fundação O Boticário de Proteção À Natureza, the Programa de Pós-Graduação em Ecologia e Recursos Naturais of Universidade Federal de São Carlos, and the Conselho Nacional de Pesquisa e Desenvolvimento (CNPq). The second author was supported by the Conselho Nacional de Pesquisa e Desenvolvimento (CNPq/PQ, Proc. 302749/2002-0). The local adminis-

Revista Brasileira de Zoologia 22 (3): 717-723, setembro 2005 
tration of São Francisco do Sul and the Clube Náutico Cruzeiro do Sul also contributed with logistic support during the initial stages of this work.

\section{REFERENCES}

Altman, J. 1974. Observational study of behaviour: sampling methods. Behaviour, Leiden, 49: 227-265.

Bordino, P.; G. Thompson \& M. IñIguez. 1999. Ecology and behaviour of the franciscana (Pontoporia blainvillei) in Bahía Anegada, Argentina. Journal of Cetacean Research and Management, Cambridge, 1 (2): 213-222.

Brownell JR., R.L. 1975. Progress report on the biology of the franciscana dolphin, Pontoporia blainvillei, in Uruguayan waters. Journal of the Fisheries Research Board of Canada, Ottawa, 32: 1073-1078.

Brownell JR., R.L. 1989. Franciscana Pontoporia blainvillei (Gervais and d'Orbigny, 1844), p. 45-47. In: S.H. RIDGWAY \& R. HARRISON (Eds). Handbook of marine mammals. London, Academic Press, 442p.

Clutton-Brock, T.W. \& P.H. Harvey. 1977. Primate ecology and social organization. Journal of Zoology, Cambridge, 183: 1-39.

Cremer, M.J.; F.A.S. Hardt; A.J. Tonello Júnior; P.C.A. SimÕes-Lopes \& J.S. PIREs. 2004a. Core areas changes in Sotalia guianensis (Cetacea, Delphinidae) population in Babitonga Bay, Santa Catarina. Revista Univille, Joinville, 9: 12-16.

Cremer, M.J.; P.C. Simões-Lopes \& J.S.R. Pires. 2004b. Interações entre aves marinhas e Sotalia guianensis (P. J. van Bénédén, 1864) na Baía da Babitonga, sul do Brasil. Revista Brasileira de Zoociências, Juiz de Fora, 6 (1): 103-114.

Crespo, E.A.; G. Harris \& R. González. 1998. Group size and distributional range of the franciscana, Pontoporia blainvillei. Marine Mammal Science, Dartmouth, 14 (4): 845-849.

Di Beneditto, A.P.; R. Ramos \& N.R.W. Lima. 2001. Sightings of Pontoporia blainvillei (Gervais \& D'Orbigny, 1844) and Sotalia fluviatilis (Gervais, 1853) (Cetacea) in Southeastern Brazil. Brazilian Archives of Biology and Technology, Curitiba, 44 (3): 291-296.

Fitch, J.E. \& R.L. BRownell JR. 1971. Food habits of the franciscana Pontoporia blainvillei (Cetacea: Platanistidae) from South America. Bulletin of Marine Science, Miami, 21 (2): 626636.

Irvine, A.B.; M.D. Scott; R.S. Wells \& J.H. Kaufmann. 1981. Movements and activities of the Atlantic bottlenose dolphin Tursiops truncatus, near Sarasota, Florida. Fishery Bulletin, La Jolla, 79 (4): 671-688.

International Union for the Conservation of Nature. 2000. Dolphins, whales and porpoises. 2002-2010 Conservation Action Plan for the world's cetaceans. Gland, R.R. REEvES, B.D. Smith, E. Crespo \& G. Notarbartolo Di Sciara, IUCN/SSC, 139p.

Instituto Brasileiro do Meio Ambiente e dos Recursos Naturais RenoVÁveIs. 1998. Proteção e Controle de Ecossistemas Costei- ros: manguezal da Baía de Babitonga. Brasília, IBAMA, Coleção Meio Ambiente, Série Estudos Pesca, 146p.

MANn, J. 1999. Behavioral sampling methods for cetaceans: a review and critique. Marine Mammal Science, Dartmouth, 15 (1): 102-122.

Marcucci, A. \& M.J. Cremer. 2003. Estudo da ecologia alimentar de Sotalia guianensis (Cetacea, Delphinidae) e Pontoporia blainvillei (Cetacea, Pontoporiidae) na região da Baía da Babitonga, Santa Catarina, Brasil. Cadernos de Iniciação à Pesquisa, Joinville, 5: 51-59.

Monteiro-Filho, E.L.A. 1992. Pesca associada entre golfinhos e aves marinhas. Revista Brasileira de Zoologia, Curitiba, 9 (1/2): 29-37.

Monteiro-Filho, E.L.A. 1995. Pesca interativa entre o golfinho Sotalia fluviatilis guianensis e a comunidade pesqueira da região de Cananéia. Boletim do Instituto de Pesca, Santos, 22 (2): 15-23.

PINEDO, M.C. 1991. Impact of incidental fishery mortality on the age structure of Pontoporia blainvillei in Southern Brazil and Uruguay. Report International Whaling Commission, Cambridge, 15 (Special Issue): 261-264.

Pinedo, M.C.; R. Praderi \& R.L. Brownell Jr. 1989. Review of the biology and status of the franciscana, Pontoporia blainvillei, p. 46-51. In: W.F. Perrin; R.L. Brownell; K. Zhou \& J. Liu (Eds). Biology and Conservation of the River Dolphins. Gland, IUCN, 173p.

Praderi, R. 1985. Relaciones entre Pontoporia blainvillei (Mammalia: Cetacea) y tiburones (Selachii) de aguas Uruguayas. Comunicaciones Zoologicas del Museo de Historia Natural de Montevideo, Montevideo, 11 (151): 1-19.

Praderi, R.; M.C. Pinedo \& E.A. Crespo. 1989. Conservation and management of Pontoporia blainvillei in Uruguay, Brazil and Argentina, p. 52-56. In: W.F. Perrin; R.L. Brownell; K. Zhou $\&$ J. Liu (Eds). Biology and Conservation of the River Dolphins. Gland, IUCN, 173p.

Richardson, W.J.; C.R. Greene; C.I. Malme \& D.H. Thomson. 1995. Marine mammals and noise. San Diego, Academic Press, $576 \mathrm{p}$.

Rodríguez, D.; L. Rivero \& R. Bastida. 2002. Feeding ecology of the franciscana (Pontoporia blainvillei) in marine and estuarine waters of Argentina. Latin American Journal of Aquatic Mammals, Rio de Janeiro, (1): 77-94.

SANTOS, M.E. \& M. LACERDA. 1987. Preliminary observations of the bottlenose dolphin (Tursiops truncatus) in the Sado estuary (Portugal). Aquatic Mammals, Moline, 13 (2): 65-80.

Schoener, T.W. 1971. Theory of feeding strategies. Annual Review of Ecology and Systematics, Palo Alto, 4: 259-271.

Secchi, E.R.; P.H. Otт; E.A. Crespo; P.G. Kinas; S.N. Pedraza \& P. Bordino. 2001. A first estimate of franciscana (Pontoporia blainvillei) abundance off southern Brazil. Journal of Cetacean Research and Management, Cambridge, 3 (1): 95-100.

SHANE, S.H. 1990. Behavior and ecology of the bottlenose dolphin at Sanibel island, Florida, p. 245-265. In: S. 
Leatherwood \& R.R. Reeves (Eds). The bottlenose dolphin. San Diego, Academic Press, 652p.

Siciliano, S. 1994. Review of small cetaceans and fishery interactions in coastal waters of Brazil. Report of the International Whaling Commission, Cambridge, 15: 241-250.

WATKINS, W.A. 1986. Whale reaction to human activities in Cape Cod waters. Marine Mammal Science, Dartmouth, 2 (4): 251-262.

Received in 06.XII.2004; accepted in 19.VIII.2005.
WÜRSIG, B. 1986. Delphinid foraging strategies, p. 347-359. In: R.J. Schusterman; J.A. Thomas \& F.G. Wood (Eds). Dolphin cognition and behavior: a comparative approach. London, Lawrence Erlbaum Associates, 393p.

Ximenez, A.; A. Langguth \& R. Praderi. 1972. Lista sistemática de los mamíferos del Uruguay - Orden Cetacea. Anales del Museo Nacional de Historia Natural de Montevideo, Montevideo, 7 (5): 29-35. 